\title{
INTEGRINS, CANCER AND SNAKE TOXINS (MINI-REVIEW)
}

\section{RÁDIS-BAPTISTA G. (1)}

(1) Department of Biochemistry and Molecular Biology, Federal University of Ceará, Picí Campus, Fortaleza, Ceará, Brazil.

ABSTRACT: Integrins encompass a family of transmembrane heterodimeric proteins of adhesion that maintain cells attached to other cells and to the extracellular matrix (ECM). Integrins work as bi-directional mechanotransducers, conveying mechanical signal from outside to inside the cell through a cascade of phosphorylation signals. On the other hand, the signal from inside to outside controls the strength and affinity of integrin adhesion. As proteins of focal contact, integrins are involved in diverse cell functions, such as cell activation, migration, growth, and survival. In the development of neoplastic disease and metastatic tumor, integrins can influence cancer invasiveness and progression, as well as mediate the formation of new blood vessels (angiogenesis). Diverse snake venom toxins have the ability to interact with multiple integrins, what results in inhibition of cell attachment, inhibition of angiogenesis, and induction of apoptotic death of tumor and vascular endothelial cells. The aim of this review is to present data about snake venom toxins that bind to integrins and evoke antiangiogenesis and antitumoral effects.

KEY WORDS: integrin, angiogenesis, cancer, apoptosis, snake toxin, snake venom C-type lectin, metalloprotease, disintegrin.

\section{CORRESPONDENCE TO:}

G. RÁDIS-BAPTISTA, Department of Biochemistry and Molecular Biology, Federal University of Ceará, Picí Campus, P.O. Box 6020, 60451-970, Fortaleza, Ceará, Brazil. Phone: +55 85288 9817. Fax: +55 85288 9789. Email: radisbra@ufc.br 


\section{INTEGRINS}

Integrins constitute a large family of focal adhesion proteins, in other words, transmembrane proteins of adhesion that keep cells attached to the extracellular matrix; the latter composed of an intricate network of proteins and polysaccharides on the cell surface (41). Integrins work as receptors for several types of cell matrix proteins, for example collagen, fibronectin, lamin, vitronectin, and fibrinogen (50).

The integrins family comprises, in mammals, at least 24 members of heterodimeric transmembrane proteins, which are formed by the noncovalent association of two glycoproteins: one $\alpha$ subunit out of 19 and one $\beta$ subunit from 9 types. The diversity of the integrins family is further increased not only by alternative mRNA splicing of some $\alpha$ and $\beta$ subunits, but also by their post-translational modification $(49,110)$. As example of integrin assembly, $\beta_{1}$ subunit associates with twelve subtypes of the $\alpha$ subunit. Thus, $\alpha 1 \beta 1, \alpha 2 \beta 1, \alpha 3 \beta 1, \alpha 4 \beta 1, \alpha 5 \beta 1, \alpha 6 \beta 1, \alpha 7 \beta 1, \alpha 8 \beta 1, \alpha 9 \beta 1, \alpha 10 \beta 1$, $\alpha 11 \beta 1$, and $\alpha v \beta 1$ are found on almost all the vertebrate cells. In contrast, $\alpha v$ subunit, where $v$ stands for vitronectin receptor, associates with more than one $\beta$ subunit, making up $\alpha v \beta 1, \alpha v \beta 3, \alpha v \beta 5, \alpha v \beta 6$, and $\alpha v \beta 8$. Multiple integrins recognize several cell matrix proteins, many of which usually contain the consensus motif of arginineglycine-aspartic acid (RGD). Extracellular divalent cations, such as $\mathrm{Ca}^{2+}$ and $\mathrm{Mg}^{2+}$, influence the specificity and affinity of integrins binding to their ligands $(8,102)$ In addition to participating in the cell matrix attachment, clustering of integrin at the sites of cell contact can activate intracellular signaling through focal adhesion kinase (FAK or pp125 $5^{\mathrm{FAK}}$ ) and via other associated proteins $(18,97)$. FAK also associates with a number of other adapter, signaling, and cytoskeletal proteins, such as paxillin, Graf (GTPase regulator associated with FAK), cytohesin-1, Grb2, p130 ${ }^{\mathrm{CAS}}$, $\alpha$-actinin, filamin, and talin $(17,92,97)$. This way, signaling from the outside to inside the cell ("outside-in" integrin signaling) induces FAK to assemble in complexes of proteins that intermediate the signal transduction. For example, once the accessory proteins paxillin and talin induce (auto-) phosphorylation of numerous tyrosine residues, in FAK cytoplasmic tails, FAK acts as a docking site for $\mathrm{SH} 2$ domains of signaling proteins, like Src and phosphatidylinositol 3-kinase (PI 3-kinase) (17, 92). In turn, Src protein mediates the phosphorylation of the $\mathrm{SH} 3$ domain-containing adapter protein, p130 ${ }^{\mathrm{CAS}}$, which promotes Crk binding and downstream signaling for cell migration. On the other hand, Grb2 directly binding to FAK, in response to integrin activation, 
initiate Ras/Erk/MAP kinase pathway, and, consequently, cell proliferation in normal and pathological states $(17,82,83,87)$. FAK is also implicated in controlling cell cycle progression via Jun $\mathrm{NH} 2$-terminal kinase (JNK) and preventing apoptosis through a pathway involving the proteins kinase C, phospholipase A2, and p53 (5, 76).

Thus, the "outside-in" signaling mediated by integrins is implicated in several cellular functions such as cell adhesion and migration, cell growth and survival, cell differential and development, tissue repair, hemostasis, and even apoptosis (8, 50, 113).

The signal from the extracellular environment into the cell, i.e. "the outside-in signaling", is not the only transduced by integrins. "Inside-out signaling pathway", in which signals inside the cell are mediated by phosphorylation of the integrin cytoplasmic tail, also operates in the regulation of the integrin affinity and adhesion strength in the site of focal contact $(3,29,108)$. The inside-out signaling is also particularly significant in the activation of platelets and white blood cells (9).

Most of the recent advances on the role of integrins (and some of their ligands) functions in vertebrate development processes came with the use of knockout mutation, mainly in mouse model $(27,49)$. As compiled by De Arcangelis and Georges-Laburesse $(27)$ and others $(35,103)$, the inactivation of the $\beta 1$ integrin gene expression, which corresponds to the lack of more than ten integrins, results in embryonic lethality. By working on the $\alpha$ subunit genes silencing, more precise integrin functions were revealed, including their role in the formation of cerebral vasculature, in the maintenance of muscle integrity, and in the development of the nervous system.

\section{INTEGRINS AND CANCER}

Tumor or neoplasm is an abnormal mass of tissue that results when cells divide without control. When tumor cells acquire the ability to invade surrounding tissues (metastasis), they become malignant, and the metastatic or malignant tumor is referred as cancer. Cancer cells can invade nearby tissues and spread through the bloodstream and lymphatic system to other parts of the body. There are several main types of cancer. Carcinoma is cancer that begins in the skin or in tissues that line or cover internal organs. Sarcoma is cancer that begins in bone, cartilage, fat, muscle, blood vessels, or other connective or supportive tissue. Leukemia is cancer that 
starts in blood-forming tissues, such as the bone marrow, and causes large numbers of abnormal blood cells to be produced and enter the bloodstream. Lymphoma and multiple myeloma are cancers that begin in the immune system cells (75).

As pointed out, integrins operate as mechanotransducer, integrating essential functions in cell development and in physiological processes, by regulating cell-cell and cell-matrix contacts. It should be noted that sites of contact between integrins and ECM, the focal adhesions, are prominent regions of signal transduction via phosphorylation. Signaling through integrin clusters and FAKs, at focal adhesions, is essential for normal cell growth and migration. Loss of ECM contacts and normal cytoskeletal structure can stimulate cancer cells growth, whereas restoration of ECM adhesion reverses this tendency (93). For example, activation of integrin $\alpha 3 \beta 1$ downregulates E-cadherin-mediated adhesion, causing loss of cell-cell adhesion and junctional communication, as well as enhancing invasiveness of malignant tumor cells (55). Obviously, reduction of adhesion and increasing of motility give cancer cells the capacity of invasion and mestatasis. In fact, in some invasive tumors, cells over-expressing FAKs or other integrin-associated protein (e.g., integrin-linked kinase, p59 ${ }^{\mathrm{ILK}}$ ) lose their contact and adherence with ECM, and become highly motile $(43,80)$, although the detachment of cell anchorage from ECM induces apoptosis in vitro and in physiological conditions. Therefore, an increase of FAK expression and downstream signaling through tyrosine phosphorylation are correlated with the behavior of cell proliferation, survival, migration, and progression to an invasive phenotype $(90,91,113)$.

The development of cancer is not a simple pathological process in which a single participant in a pathway has a primordial role in the disease progression. In this context, integrins not only mediate some direct effects in cancer fates due to their involvement in cellular response to chemical signaling and attachment, but also have an indirect participation by conveying molecular signaling for the development of new blood vessels, which will nourish the growing tumor mass.

In truth, it was realized more than 100 years ago that angiogenesis occurs in tumors. In the early 70's, Dr. Judah Folkman proposed that tumor growth and metastasis are dependent on angiogenesis and that detaining new blood vessel formation might be an effective therapeutical strategy to arrest tumor growth (36). It was recognized that tumor expansion outside the limit of 1 to $2 \mathrm{~mm}$ in size is extremely dependent on the recruitment of new blood vessels. The angiogenesis process is regulated in a tissue 
by the balance between angiogenic factors and inhibitors, and involves activation of several receptors on endothelial vascular cells, including integrins.

\section{INTEGRIN AND VASCULAR DEVELOPMENT}

In both vasculogenesis and angiogenesis, vessel formation is a dynamic, complex biological process that depends on interactions with regulatory factors and adhesive substrates. Although both processes utilize practically common molecular components in the vessel development, they have different origins. Angiogenesis is the process of growth of new capillaries from pre-existing blood vessels and, in contrast, vasculogenesis only develops during embriogenesis from pluripotent blood cells (86).

In mammals, angiogenesis is involved in both physiological and pathological processes, and multicellular organisms must recruit new blood vessels to grow beyond the limit of oxygen diffusibility $(100-200 \mu \mathrm{m})$. In normal tissue growth, such as in embryonic development, there is a dependence on new vessel formation, while menstrual cycle and wound healing are characterized by transient neovascularization from quiescent vascular endothelial cells (101).

Proper activation of angiogenesis depends on the proliferation, adhesion, migration, and maturation of endothelial cells. Several factors contribute to each individual process, and the balance between angiogenic factors and endogenous angiogenic inhibitors is the key component affecting the development of new vessels. For example, one of the major players in angiogenesis initiation is the powerful stimulator vascular stimulator growth factor (VEGF). This growth factor is under the control of the hypoxia-inducible factor (HIF), and is up-regulated under hypoxic or ischemic condition (39). VEGF is abundantly produced by hypoxic tumor cells and by several cell lines of the immune system, although the host cells also contribute to tumor angiogenesis $(11,72,104,109)$.

As emphasized, integrins are transmembrane proteins that mediate cell-cell and cellECM adhesion and bi-directional signal transduction, and thus they participate in many aspects of vasculogenesis and angiogenesis (reviewed in 85). At least seven integrin heterodimers are present in endothelial cells: $\alpha 1 \beta 1, \alpha 2 \beta 1, \alpha 3 \beta 1, \alpha 5 \beta 1, \alpha 6 \beta 1$, $\alpha v \beta 3$, and $\alpha v \beta 5$, and their activation and differential expression are finely regulated in response to several angiogenic factors $(46,94,95,96,111)$. In the development and 
remodeling of vascular system, these integrins are directly involved in matrix assembling, in which they interact with ECM proteins and mediate cell attachment and migration. In addition, through the inside-out and outside-in bi-directional signaling and in association with other non-receptor tyrosine kinases, they also mediate agonist affinity and specificity, gene expression, shaping, and survival of vascular cells $(34,60,97)$.

Several pathological conditions are associated with abnormal angiogenesis. These include arteriosclerosis, scar keloids, psoriasis, endometriosis, obesity, rheumatoid arthritis, inflammatory and infectious processes, diabetes, retinopathy, tumor growth, and metastasis, among others $(16,37)$. Thus, the inhibition of angiogenesis was adopted as a therapeutic strategy for the treatment of cancer and other diseases, in which neovascularization is one of the pathological components $(14,38,87)$. As recently reviewed (15), more than 60 angiogenesis inhibitors are being evaluated for their anticancer effects in human patients. These compounds encompass integrin antagonists, blockers of VEGF-, FGF-, and PDGF-receptors, natural and synthetic matrix metalloproteases (MMPs), and monoclonal antibodies, among others.

\section{INTEGRINS, CANCER, AND SNAKE TOXINS}

As mentioned above, integrins play significant roles in angiogenesis, in addition to the signal transduction that affects cell behaviors, like cancer spreading. Therefore, one strategy to undermine cancer progression is to target integrins either on tumor cells or on vascular endothelial cells that are recruited by cancer. One particular importance in targeting integrins is that they are differentially distributed in adult human tissue. For example, a high level of $\alpha \mathrm{v} \beta 3$ integrin is expressed in endothelial cells, which are exposed to various growth factors, or in cells undergoing normal or pathological neovascularization (34). It is noteworthy that $\alpha v \beta 3$ and $\alpha v \beta 5$ integrins are also expressed in some types of invasive tumors, correlating with cancer aggressiveness. In addition, up- or down-regulation of integrin expression sub-types determines the incidence of such diseases and the patient prognosis (87).

It is well known that some snake venoms contain toxins with the ability to bind to integrins and interfere with cell-cell and cell-ECM adhesion by integrin binding. For instance, the integrins $\alpha 2 \beta 1$ (glicoprotein la/lla, GPla/lla) and $\alpha$ llb $\beta 3$ (GPIIb/IIla) expressed on platelet membranes, are the targets for several snake toxins, which 
inhibit or promote platelet aggregation $(1,2)$. Among the toxins from snake venom that bind to integrin $\alpha 2 \beta 1$ (GPla/lla) promoting platelet aggregation are aggretin, from Calloselasma rhodostoma (21); bilinexin, from Agkistrodon bilineatus (32); crovidisin, from Crotalus viridis (61); EMS16, from Echis multisquamatus (48); jararhagin, from Bothrops jararaca $(28,52)$; and rhodocetin, from Calloselasma rhodostoma (112). After binding to the integrin, the induction of platelet activation by some of these toxins initiates a cascade of phosphorylation conducted by $\mathrm{p} 125^{\mathrm{FAK}}$ and $\mathrm{p} 72^{\mathrm{SYC}}$ (serine-tyrosine kinase, SYK), as reported for aggretin (74).

Some snake toxins acting on the integrin $\alpha \mathrm{llb} \beta 3$, which causes inhibition of platelet aggregation, are reported: barbourin, from Sistrurus $m$. barbouri (89); CC5 and CC8, from Cerastes cerastes (12); crotavirin, from Crotalus viridis (62); echistatin, from Echis carinatus (40,44); eristotatin, from Eristocophis macmahoni (71); piscivostatin, from Agkistrodon piscivorous piscivorous (77); Sal-C and salmosin, from Agkistrodon halys brevicaudus $(22,59)$; saxatilin, from Gloydius saxatilis (47); Schistatin, from Echis carinatus (107).

It should be noted that most snake toxins acting on these integrins belong to the families of C-type lectins, disintegrins, and metalloproteases. Snake venom C-type lectins contain the conserved carbohydrate recognition domain (CRD) of other animal C-type lectin and share significant primary structure similarities with them, but they not necessarily bind to carbohydrate molecules nor require calcium ions for their activity. Unlike the classic C-type lectins, those from snake venoms are generally heterodimeric, with two subunits, alpha and beta, and some of them are multimeric heterodimers $(2,23,31)$. Metalloproteases constitute prominent components of viperid and crotalid venom with the ability to hydrolyze extracellular matrix proteins, interfere with cell-ECM and cell-cell adhesion, and consequently cause hemorrhage. High molecular weight (20 to $100 \mathrm{kDa}$ ) metalloproteases are referred as metalloproteinase/disintegrin-like/cysteine (MDC) rich proteins, since they have a $\mathrm{N}$ terminal catalytic site, a disintegrin-like interacting domain (usually RGD), and a hydrophobic cell-cell fusion domain in cysteine-rich C-terminus (53). Disintegrins are low molecular weight, non-enzymatic, polypeptides, rich in residues of cysteine, containing, in general, the RGD motif with the ability to interact with integrins on the cell membrane $(53,66)$.

It is noteworthy that ECM-degrading metalloproteases including members of the metzincins family, such as ADAMs (a disintegrins and metalloproteinase domain) and 
adamalysins-like enzymes, constitute extrinsic regulators of epithelial tumor progression (7). In fact, proteolysis of ECM components, including growth factor precursors embedded (sequestered) in or anchored to ECM, is a key process during cell adhesion, growth and differentiation; tissue morphogenesis; wound healing; and conversion of benign tumors into invasive malignant metastatic cancer $(4,30,81)$.

Paradoxically, it has been reported the ability of some snake venom components, belonging to the metalloprotease/disintegrin family, to inhibit in vitro cell migration, adhesion/detachment, proliferation and in vivo cancer progression. For instance, vascular apoptosis-inducing proteins 1 and 2 (VAP1 and VAP2), from the venom of western diamondback rattlesnake (Crotalus atrox), as their names suggest, induce in vitro apoptotic death of vascular endothelial cells, and the integrins $\alpha 3 \beta 1$ and $\alpha 6 \beta 1$ are involved $(69,70)$. Crovidisin, a PIII snake venom metalloproteinase purified from western rattlesnake (Crotalus viridis) venom, causes detachment of ROS 17/2.8 osteosarcoma cells, but not of primary cultured osteoblasts from extracellular matrix proteins. The proteolysis of extracellular matrix proteins by crovidisin was implicated in the selective detachment (106).

At this point, it would be necessary to clarify the mechanisms of the apparently contradicting roles of metalloproteases in the facilitation of cancer progression or in the restrain of tumor evolution. It was verified that some proteolytic fragments of ECM proteins act as inhibitors of neoplastic growth $(7,42)$. The explanation is validate by the remarkable works of O'relly and collaborators $(78,79)$ that isolated plasminogen and collagen XVIII fragments able to block angiogenesis and the spreading of metastasis. Thus metalloproteases can, not only promote cancer proliferation and invasion, but also suppress tumor growth by generating inhibitory proteolytic fragments that can interact to transmembrane receptors, such as integrins and other adhesion proteins, (over-) expressed in cancer and in vascular endothelial cells.

Snake toxins belonging to the families of C-type lectins and disintegrins, acting on cell migration, adhesion and proliferation, have also been isolated and characterized. Consequently, proteolysis of ECM components is not the sole essential mechanism by which snake toxins commit the cell fate. For instance, contorstrostatin, a homodimeric disintegrin from Agkistrodon contortix contortix venom, induces protein phosphorylation in T24 human bladder cancer cells via integrin-mediated signaling, which includes the integrin-FAK-adapter protein $\mathrm{p} 130^{\mathrm{CAS}}$. In contrast, the monomeric disintegrins echistatin and flavoridin from saw-scaled viper (E. carinatus) and habu 
snake (Trimeresurus flavoviridis) venoms, respectively, do not induce protein phosphorylation (85). Salmosin is a disintegrin purified from the venom of the Korean snake (Agkistrodon halys brevicaudus). In addition to antagonizing the platelet integrin GPIIb-IIla, it interacts with the integrin $\alpha v \beta 3$ and inhibits the proliferation of bovine capillary endothelial (BCE) cells induced by the basic fibroblast growth factor (bFGF). In BCE cells treated with salmosin, focal adhesion kinase (FAK) was dephosphorylated and the expression of paxillin and $\mathrm{p} 130^{\mathrm{CAS}}$ was decreased, but PI3 kinase, and other FAK adapter proteins are deregulated, suggesting that salmosin induces apoptosis of BCE cells by inactivating FAK-dependent integrin signaling pathways (45).

Several other disintegrins are able to interfere with experimental tumor metastasis. Eristostatin, from the venom of the leaf-nosed viper (Eristocophis macmahonii), bound to integrins on each B16F1 melanoma cell injected into C57BL/6 mice and reduced the number of growing cells (73). This disintegrin requires the RGDW motif, as well as an intact C-terminus to interact with both platelets and melanoma cell lines, which include 1205-LU, WM164, C8161, and MV3 (71).

Likewise, albolabrin, from the venom of the green pit viper (Trimeresurus albolabris); barbourin, from the dusky pigmy rattlesnake (Sistrurus miliarius barbouri) venom; and echistatin, inhibited the formation of experimental lung metastases induced by IV injection of B16F10 murine melanoma cells into C57BL/6 mice (10). Trigramin, isolated from the venom of the Indian green tree viper (Trimeresurus gramineus) snake, has the RGD motif and inhibits the adhesion of human melanoma cells to fibronectin and fibrinogen (58). In addition, trigramin and rhodostomin (a disintegrin from the venom of the Malayan pit viper - Calloselasma rhodostoma) prevent platelet aggregation induced by SW-480 tumor cell, derived from a primary human colon adenocarcinoma, and by MCF-7 cells, a metastatic human breast carcinoma line (19, 20).

One of the C-type lectins with the ability to inhibit the integrin-mediated attachment to ECM components of various tumor cell lines is lebectin. Lebectin was isolated from the venom of Levantine viper ( $M$. lebetina). It was also able to block cell migration towards fibronectin, and prevented invasion of fibrin gels by tumor cells. Moreover, lebectin showed an inhibitory effect on tumor cell proliferation (88).

Most snake venom toxins exert their inhibitory effects on cell adhesion, migration and proliferation through the interaction with integrins expressed on the cell surface. In 
fact, contorstrostatin binds to the integrins $\alpha \mathrm{llb} \beta 3, \alpha 5 \beta 1$, and $\alpha \mathrm{v} \beta 3$, and inhibits adhesion and invasion of cancer cells (118). The disintegrins echistatin, flavoridin (from Trimerusurus flavoviridis venom), and kistrin (from Calloselasma rhodostoma), bind with high affinity to immobilized $\alpha \mathrm{v} \beta 3$ in solid phase assay (51). Eristostatin seems to interfere with $\alpha 4 \beta 1-V C A M$ binding, thus it strongly inhibits lung colonization of MV3 cells in nude mice injected with tumor cells (25). EMS16, another snake venom C-type lectin, isolated from Echis multisquamatus, selectively binds to the $\alpha 2$ I domain of $\alpha 2 \beta 1$ integrin and inhibits collagen-induced platelet aggregation. EMS16 also binds to the integrin $\alpha 2$ transfected K562 cells and inhibits the human umbilical vein endothelial cells (HUVEC) migration in collagen I gel (64). Rhodostomin blocks the integrin $\alpha v \beta 3$ on human vascular endothelial cells thus inhibiting distinct steps in angiogenesis elicited by basic fibroblast growth factor (bFGF) and suppressing murine melanoma tumor growth in vivo. To verify the binding of rhodostomin to the integrin $\alpha v \beta 3$, a monoclonal $\alpha v \beta 3$ antibody (mAb) selectively inhibited the binding of rhodostomin to both naive and bFGF-primed HUVECs (115).

A striking number of papers have been published on snake venom toxins, which cover the range of specificities to every mammalian integrin subtype, including the integrins $\alpha 1 \beta 1, \alpha 3 \beta 1, \alpha 4 \beta 1, \alpha 5 \beta 1, \alpha 5 \beta 3, \alpha 6 \beta 1, \alpha 6 \beta 4, \alpha 7 \beta 1, \alpha 9 \beta 1, \alpha v \beta 3, \alpha \beta 5$, and $\alpha \mathrm{M}(\beta 2)$. Most importantly, snake venom toxins interact with integrins according to their specificity and interfere with cell adherence, invasiveness, and survival, but to different extent.

For instance, halysase, a monomeric DECD-metalloprotease isolated from the venom of halys viper (Gloydius halys), strongly inhibits the proliferation of human umbilical vein of endothelial cells in a dose-dependent manner and inhibits the adhesion of these cells to extracellular matrix proteins through the interaction with integrins $\alpha 1 \beta 1$ and $\alpha 5 \beta 1$. It is also able to induce apoptosis of endothelial cells by activating caspase-3 and decreasing the level of BcL-X(L)/Bax (116). Lebein-1 (known as lebein) and lebein-2, two RGD-containing desintegrins purified from the venom of Vipera lebetina, strongly interacts with the integrins $\alpha 3 \beta 1, \alpha 6 \beta 1$, and $\alpha 7 \beta 1$, but not with the collagen-binding $\alpha 1 \beta 1$ and $\alpha 2 \beta 1$ integrins. In cell attachment assays, lebein-1 and lebein-2 inhibited myoblast attachment not only to laminin, but also to fibronectin. However, the interaction seemed to be RGD-independent and, in some way, the toxins mimic a yet unknown integrin-binding structure of laminins (33). Three 
non-RGD heterodimeric disintegrins, VLO5, EO5, and EC3, from the venom of Vipera lebetina obtusa, Echis ocellatus, and E. carinatus, respectively, are potent inhibitors of $\alpha 4 \beta 1, \alpha 4 \beta 7$, and $\alpha 9 \beta 1$ integrins expressed in leukocytes (6). Furthermore, it was showed that VLO5, and other five novel disintegrins, VLO4, VB7, VA6, EO4, and EMS11, from the venom of V. I. obtusa, V. berus, V. ammodytes, Echis ocellatus, and E. multisquamatus, blocked the adhesion of the $\alpha 4 \beta 1$ integrin to vascular cell adhesion molecule 1 (VCAM-1) with high specificity. While the desintegrin EMS11 inhibited both $\alpha 5 \beta 1$ and $\alpha 4 \beta 1$ integrins with almost the same degree of specificity (13). The heterodimeric MLDG-disintegrins (non-RGD) EC3 and EC6, from E. carinatus venom, exhibited specificity towards the integrins $\alpha 4 \beta 1$ and $\alpha 9 \beta 1$. Both EC3 and EC6 were potent inhibitors of $\alpha 9 \beta 1$ mediated adhesion to VCAM-1 and of neutrophils migration across the layer of endothelial cells activated by tumor necrosis factor (65). Snake venom disintegrins capable of interfering with integrin $\alpha \mathrm{M}$ were also characterized, but they evoke responses other than cell detachment and apoptosis. For example, jarastatin, a monomeric RGD-disintegrin from the venom of jararaca (Bothrops jararaca), inhibts neutrophil chemotaxis induced by fMet-Leu-Phe. Comparison of JT and EC3 indicated that both chemotactic disintegrins induce the activation of FAK and PI 3-kinase. However, they are different in that, while JT delays apoptosis of neutrophil via activation of Erk-2, EC3 inhibits Erk-2 signaling and holds a proapoptotic activity (24). HF3 is another component of $B$. jararaca venom, which mediated cell function by means of interaction with the integrin $\alpha \mathrm{M}$. HF3 belongs to the class P-III and contains the typical disintegrin-like/cysteine-rich domains. It was shown that both native and recombinant HF3 increase $\alpha \mathrm{M} \beta 2$-mediated phagocytosis of opsonized-zymosan particles by macrophages (100).

As mentioned, $\alpha \vee \beta 3$ and $\alpha \vee \beta 5$ are the main integrins expressed in vascular endothelial cells and in several types of tumor. Toxins targeting $\alpha \vee \beta 3$ and $\alpha \vee \beta 5$ integrins have been isolated from viper and pit viper venoms. Accutin, which was purified from the venom of Agkistrodon acutus (or Deinagkistrodon acutus) and is also a member of the disintegrin family, inhibits not only human platelet aggregation by blocking the binding of fibrinogen to the platelet GPIIb/llla (integrin $\alpha$ llb $\beta 3$ ), but also the adhesion of HUVEC to immobilized ECM proteins, such as fibrinogen, fibronectin and vitronectin. It also inhibits capillary-like tube formation on Matrigel in a dose- and RGD-dependent manner, and angiogenesis in vivo, when assayed in chick 
embryo chorioallantoic membranes (CAM) model, while it induces apoptotic DNA fragmentation in HUVEC. All these effects were triggered by toxin binding to the integrin $\alpha \vee \beta 3$ (114). Contortrostatin, described above, blocks the adhesion of the human epithelial carcinoma cell line of the ovary (OVCAR-5) to extracellular matrix proteins and inhibits tumor cell invasion. In addition, contortrostatin not only inhibited ovarian cancer dissemination significantly, but it dramatically suppressed the recruitment of blood vessels to tumorsin, a xenograft nude mouse model implanted with OVCAR- 5 cells (67). Salmosin also binds to the $\alpha v \beta 3$ integrin expressed on the vascular endothelial cell and thus block tumor-induced angiogenesis (54). Likewise, by interacting with $\alpha v \beta 3$ integrin, salmolisin inhibits the proliferation of SK-Mel-2 human melanoma cells and the metastasis of B16 melanoma cells $(22,57)$. The antitumor effect of salmosin was suggested to be due to its antiangiogenic activity, since the recombinant proteins inhibited proliferation of bovine capillary endothelial (BCE) cells and effectively inhibited the migration of highly metastatic B16BL6 mouse melanoma cells. Besides, recombinant salmosin inhibited neovascularization in CAM and in Matrigel implanted subcutaneously into mice (56). Another snake disintegrin able to bind to $\alpha v \beta 3$ integrin and to inhibit adhesion of tumor cells to ECM proteins is triflavin, isolated from the venom of Trimeresurus flavoviridis (99). By the interaction with integrin $\alpha v \beta 3$, triflavin inhibited the in vitro adhesion of HUVECs to ECMs (vitronectin, fibronectin, laminin, and collagen type IV), and suppressed TNF $\alpha$ induced angiogenesis in CAM assay. Moreover, triflavin inhibits the adhesion of hepatoma cell to extracellular matrices by binding to the integrins $\alpha v \beta 3, \alpha 3 \beta 1$, and $\alpha 5 \beta 1$, expressed on the surface of hepatoma cells (98).

There are snake venoms or toxins that are able to inhibit cell adhesion to ECM proteins, induce apoptotic cell death and restrain cell proliferation, of which binding specificities or the venom component responsible for binding are not fully characterized yet. For example, components from Macrovipera lebetina and Cerastes cerastes venoms bind to IGR39 melanoma cells but not to HT29-D4 cells that derived from colonic adenocarcinoma. However, these venoms inhibit the adherence of IGR39 and HT29-D4 to various extracellular matrix proteins (68). Lebectin, a C-type lectin, was then isolated from the venom of $M$. lebetina (88). Lebectin inhibited the integrin-mediated attachment of various tumor cell lines, and the integrin $\alpha 5 \beta 1$ might be the target for lebectin, but it still needs further characterization. Zhao and 
collaborators (117) demonstrated that the crude venom of western diamond rattlesnake (Crotalus atrox) contains at least one important target-component to integrin $\beta 4$, and this component is responsible for the early phase of apoptosis in vascular endothelial cells, mediated by integrin signaling and over expression of p53. Lipps (63) had purified from the venoms of Crotalus atrox and Naja naja kaouthia, two cancer inhibitors named atroporin and kaotree, respectively. As noted, atroporin and kaotree inhibited various types of human and animal cancer cells, in low concentrations, and did not cause any damage to normal cells. Both atroporin and kaotree were able to not only prevent the formation, but also induce the regression of ascitic tumors in Balb/C mice inoculated with myeloma cells. The crude venom of Bothrops jararaca and Crotalus durissus terrificus exhibit antitumoral activity against Ehrlich ascite tumor cells. Nevertheless, the antitumoral effect seemed to be mediate by inflammatory response, in which toxin-activated macrophages release tumor necrosis factor and interleukins (26).

Apart of the fundamental research on snake venom proteins, such as metalloproteases, disintegrin and C-type lectins, in the scope of molecular cell biology of tumor, the prospective of the development of a cancer treatment adjuvant from snake toxins is promising. Thus far, clinically significant for the purposes of anticancer therapy, the complexation of integrin-target toxins with liposomes improves their effective therapeutic levels, their circulatory half-life and facilitates their administration. For instance, salmosin gene subcutaneously administered with cationic liposomes in vivo resulted in a systemic expression of the gene product, inhibition of the B16BL6 melanoma cells growth, and suppression of pulmonary metastases (57). Liposome release of contortrostatin, by means of intravenous administration, maintains the potent antiangiogenic activity of naive toxin and restrains breast cancer progression, as demonstrated with a xenograft human mammary tumor model (105).

\section{CONCLUDING REMARKS}

It should be noted that the compilation of data concerning to toxins acting specifically on integrins, which are differentially expressed on the membrane of several mammalian cell types, such as platelets, vascular endothelial cells, and mainly immortalized and cancer cells, was aimed. Evidently, much more snake venom toxins acting on the diverse number of integrins can be found. Here some of them were 
presented to illustrate the specific interaction between target-integrin and snake toxins that can modulate cell function and fate. Collectively, the information offers a vision of the medical and biotechnological potentialities contained in the snake venom per se, and in the particular classes of toxins, like those treated here, useful for cancer research and control.

\section{ACKNOWLEDGEMENTS}

I am very thankful to Dr. Kenichi Furihata, at SRL Inc., Tokyo, Japan, for critically read this manuscript and for significant suggestions. I am very grateful to Dr. Tetsuo Yamane, at the Center of Molecular Biology, Nuclear Energy Research Institute, IPEN, São Paulo, Brazil, and Center of Biotechnology of Amazonas, Manaus, Amazonas, Brazil, for the constant and invaluable discussion on Molecular Toxinology and Chemical Ecology. I manifest my gratitude to CAPES, CNPq, and FUNCAP for the financial support.

\section{REFERENCES}

1 ANDREWS RK., BERNDT MC. Snake venom modulators of platelet adhesion receptors and their ligands. Toxicon, 2000, 38, 775-91.

2 ANDREWS RK., KAMIGUTI AS., BERLANGA O., LEDUC M., THEAKSTON RDG., WATSON SP. The use of snake venom toxins as tools to study platelet receptor for collagen and von Willebrand factor. Haemostasis, 2001, $31,155-72$.

3 ARNAOUT MA., Integrin structure: new twists and turns in dynamic cell adhesion. Immunol. Rev., 2002, 186, 125-40.

4 ARRIBAS J., COODLY L., VOLLMER P., KISHIMOTO TK., ROSE-JOHN S., MASSAGUE J. Diverse cell surface protein ectodomains are shed by a system sensitive to metalloprotease inhibitors. J. Biol. Chem.,1996, 271, 11376-82.

5 ASSOIAN RK., SCHWARTZ MA. Coordinate signaling by integrins and receptor tyrosine kinases in the regulation of G1 phase cell-cycle progression. Curr. Opin. Genet. Dev., 2001, 11, 48-53. 
6 BAZAN-SOCHA S., KISIEL DG., YOUNG B., THEAKSTON RDG., CALVETE JJ., SHEPPARD D., MARCINKIEWICZ C. Structural requirements of MLDcontaining disintegrins for functional interaction with alpha 4 beta 1 and alpha 9 beta1 integrins. Biochemistry, 2004, 43, 1639-47.

7 BERGERS G., COUSSENS LM. Extrinsic regulators of epithelial tumor progression: metalloproteinases. Curr. Opin. Genet. Dev., 2000, 10, $120-7$.

8 BERMAN AE., KOZLOVA NI. Integrins: structure and functions. Membr. Cell Biol., $2000,13,207-44$.

9 BERTON G., LOWELL CA. Integrin signalling in neutrophils and macrophages. Cell Signal., 1999, 11, 621-35.

10 BEVIGLIA L., STEWART GJ., NIEWIAROWSKI S. Effect of four disintegrins on the adhesive and metastatic properties of B16F10 melanoma cells in a murine model. Oncol. Res., 1995, 7, 7-20.

11 BROWN LF., BERSE B., JACKMAN RW., TOGNAZZI K., GUIDI AJ., DVORAK HF., SENGER DR., CONNOLLY JL., SCHNITT SJ. Expression of vascular permeability factor (vascular endothelial growth factor) and its receptors in breast cancer. Hum. Pathol., 1995, 26, 86-91.

12 CALVETE JJ., FOX JW., AGELAN A., NIEWIAROWSKI S., MARCINKIEWICZ C. The presence of the WGD motif in CC8 heterodimeric disintegrin increases its inhibitory effect on $\alpha \operatorname{llb} \beta 3, \alpha v \beta 3$, and $\alpha 5 \beta 1$ integrins. Biochemistry, 2002, $41,2014-21$.

13 CALVETE JJ., MORENO-MURCIANO MP., THEAKSTON RD., KISIEL DG, MARCINKIEWICZ C. Snake venom disintegrins: novel dimeric disintegrins and structural diversification by disulphide bond engineering. Biochem. J., 2003, 372, 725-34.

14 CAO Y. Antiangiogenic cancer therapy. Semin. Cancer Biol., 2004, 14, 139-45.

15 CAO Y. Endogenous angiogenesis inhibitors and their therapeutic implications. Int. J. Biochem. Cell Biol., 2001, 33, 357-69.

16 CARMELIET P., JAIN RK. Angiogenesis in cancer and other diseases. Nature, 2000, 407, 249-57.

17 CARY LA., GUAN JL., Focal adhesion kinase in integrin-mediated signaling. Front. Biosci., 1999, 15, 102-13.

18 CARY LA., HAN DC., GUAN JL. Integrin-mediated signal transduction pathways. Histol. Histopathol., 1999, 14, 1001-9. 
19 CHIANG HS., SWAIM MW., HUANG TF. Characterization of platelet aggregation induced by human colon adenocarcinoma cells and its inhibition by snake venom peptides, trigramin and rhodostomin. Br. J. Haematol., 1994, 87, 325-31.

20 CHIANG HS., SWAIM MW., HUANG TF. Characterization of platelet aggregation induced by human breast carcinoma and its inhibition by snake venom peptides, trigramin and rhodostomin. Breast Cancer Res. Treat., 1995, 33, 225-35.

21 CHUNG CH., PENG HC., HUANG TF. Aggretin, a C-type lectin protein, induces platelet aggregation via integrin $\alpha 2 \beta 1$ and GPIb in a phosphatidylinositol 3kinase independent pathway. Biochem. Biophys. Res. Commun., 2001, 285, 689-95.

22 CHUNG KH., KIM SH., HAN KY., SOHN YD., CHANG SI., BAEK KH., JANG Y., KIM DS., KANG IC. Inhibitory effect of salmosin, a Korean snake venomderived disintegrin, on the integrin $\alpha \mathrm{V}$-mediated proliferation of SK-Mel-2 human melanoma cells. J. Pharm. Pharmacol., 2003, 55, 1577-82.

23 CLEMETSON KJ., NAVDAEV A., DORMANN D., DU XY., CLEMETSON JM. Multifunctional snake C-type lectins affecting platelets. Haemostasis, 2001, 31, 148-54.

24 COELHO AL., DE FREITAS MS., MARIANO-OLIVEIRA A., RAPOZO DC., PINTO LF., NIEWIAROWSKI S., ZINGALI RB., MARCINKIEWICZ C., BARJA-FIDALGO C. RGD- and MLD-disintegrins, jarastatin and EC3, activate integrin-mediated signaling modulating the human neutrophils chemotaxis, apoptosis and IL-8 gene expression. Exp. Cell Res., 2004, 292, 371-84.

25 DANEN EH., MARCINKIEWICZ C., CORNELISSEN IM., VAN KRAATS AA., PACHTER JA., RUITER DJ., NIEWIAROWSKI S., VAN MUIJEN GN. The disintegrin eristostatin interferes with integrin $\alpha 4 \beta 1$ function and with experimental metastasis of human melanoma cells. Exp. Cell Res., 1998, 238, 188-96.

26 DA SILVA RJ., FECCHIO D., BARRAVIERA B. Antitumor effect of snake venoms. J. Venom. Anim. Toxins, 1996, 2, 79-90. 
27 DE ARCANGELIS A., GEORGES-LABOUESSE E. Integrin and ECM functions: roles in vertebrate development. Trends Genet., 2000, 16, 389-95.

28 DE LUCA M., WARD CM., OHMORI K., ANDREWS RK., BERNDT MC. Jararhagin and jaracetin: novel snake venom inhibitors of the integrin collagen receptor, $\alpha 2 \beta 1$. Biochem. Biophys. Res. Commun., 1995, 206, 570-6.

29 DEDHAR S. Integrins and signal transduction. Curr. Opin. Hematol., 1999, 6, 3743.

30 DONG J., OPRESKO LK., DEMPSEY PJ., LAUFFENBURGER DA., COFFEY RJ., WILEY HS. Metalloprotease-mediated ligand release regulates autocrine signaling through the epidermal growth factor receptor. Proc. Natl. Acad. Sci. U.S.A., 1999, 96, 6235-40.

31 DRICKAMER K. C-type lectin-like domains. Curr. Opin. Struct. Biol., 1999, 9, 585-90.

32 DU XY., NAVDAEV A., CLEMETSON JM., MAGNENAT E., WELLS TN., CLEMETSON KJ. Bilinexin, a snake C-type lectin from Agkistrodon bilineatus venom agglutinates platelets via GPIb and $\alpha 2 \beta 1$. Thromb. Haemost., 2001, $86,1277-83$.

33 EBLE JA., BRUCKNER P., MAYER U. Vipera lebetina venom contains two disintegrins inhibiting laminin-binding $\beta 1$ integrins. J. Biol. Chem., 2003, 278, 26488-96.

34 ELICEIRI BP., CHERESH DA. The role of $\alpha \mathrm{v}$ integrins during angiogenesis. Mol. Med., 1998, 4, 741-50.

35 FASSLER R., PFAFF M., MURPHY J., NOEGEL AA., JOHANSSON S, TIMPL R., ALBRECHT R. Lack of $\beta 1$ integrin gene in embryonic stem cells affects morphology, adhesion, and migration but not integration into the inner cell mass of blastocysts. J. Cell Biol., 1995, 128, 979-88.

36 FOLKMAN J. Tumor angiogenesis: therapeutic implications. N. Engl. J. Med., $1971,285,1182-6$.

37 FOLKMAN J. Angiogenesis in cancer, vascular, rheumatoid and other disease. Nat. Med., 1995, 1, 27-31.

38 FOLKMAN J., BROWDER T., PALMBLAD J. Angiogenesis research: guidelines for translation to clinical application. Thromb. Haemost., 2001, 86, 23-33. 
39 FORSYTHE JA., JIANG BH., IYER NV., AGANI F., LEUNG SW., KOOS RD, SEMENZA GL. Activation of vascular endothelial growth factor gene transcription by hypoxia-inducible factor 1. Mol. Cell Biol., 1996, 16, 4604-13.

40 GAN ZR., GOULD RJ., JACOBS JW., FRIEDMAN PA., POLOKOFF MA.

Echistatin. A potent platelet aggregation inhibitor from the venom of the viper, Echis carinatus. J. Biol. Chem., 1988, 263, 19827-32.

41 GIANCOTTI FG., RUOSLAHTI E. Integrin signaling. Science, 1999, 285,102832.

42 HANAHAN D., FOLKMAN J., Patterns and emerging mechanisms of the angiogenic switch during tumorigenesis. Cell, 1996, 86, 353-64.

43 HANNIGAN GE., LEUNG-HAGESTEIJN C., FITZ-GIBBON L., COPPOLINO MG., RADEVA G., FILMUS J., BELL JC., DEDHAR S. Regulation of cell adhesion and anchorage-dependent growth by a new $\beta 1$-integrin-linked protein kinase. Nature, 1996, 379, 91-6.

44 HANTGAN RR., STAHLE MC., CONNOR JH., LYLES DS., HORITA DA., ROCCO M., NAGASWAMI C., WEISEL JW., MCLANE MA. The disintegrin echistatin stabilizes integrin alphallbbeta3's open conformation and promotes its oligomerization. J. Mol. Biol., 2004, 342, 1625-36.

45 HONG SY., LEE H., YOU WK., CHUNG KH., KIM DS., SONG K. The snake venom disintegrin salmosin induces apoptosis by disassembly of focal adhesions in bovine capillary endothelial cells. Biochem. Biophys. Res. Commun., 2003, 302, 502-8.

46 HONG YK., LANGE-ASSCHENFELDT B., VELASCO P., HIRAKAWA S., KUNSTFELD R., BROWN LF., BOHLEN P., SENGER DR., DETMAR M. VEGF-A promotes tissue repair-associated lymphatic vessel formation via VEGFR-2 and the $\alpha 1 \beta 1$ and $\alpha 2 \beta 1$ integrins. FASEB J., 2004, 18, 1111-3.

47 HONG SY., SOHN YD., CHUNG KH., KIM DS. Structural and functional significance of disulfide bonds in saxatilin, a $7.7 \mathrm{kDa}$ disintegrin. Biochem. Biophys. Res. Commun., 2002, 293, 530-6.

48 HORII K., OKUDA D., MORITA T., MIZUNO H. Structural characterization of EMS16, an antagonist of collagen receptor (GPla/lla) from the venom of Echis multisquamatus. Biochemistry, 2003, 42, 12497-502.

49 HUMPHRIES MJ. Integrin structure. Biochem. Soc. Trans., 2000, 28, 311-39. 
50 HYNES RO. Integrins: versatility, modulation, and signaling in cell adhesion. Cell, 1992, 69, 11-25.

51 JULIANO D., WANG Y., MARCINKIEWICZ C., ROSENTHAL LA., STEWART GJ., NIEWIAROWSKI S. Disintegrin interaction with $\alpha \mathrm{V} \beta 3$ integrin on human umbilical vein endothelial cells: expression of ligand-induced binding site on $\beta 3$ subunit. Exp. Cell Res., 1996, 225, 132-42.

52 KAMIGUTI AS., HAY CR., ZUZEL M. Inhibition of collagen-induced platelet aggregation as the result of cleavage of $\alpha 2 \beta 1$-integrin by the snake venom metalloproteinase jararhagin. Biochem. J., 1996, 320, 635-41.

53 KAMIGUTI AS., ZUZEL M, THEAKSTON RD. Snake venom metalloproteinases and disintegrins: interactions with cells. Braz. J. Med. Biol. Res., 1998, 31, 853-62.

54 KANG IC., LEE YD., KIM DS. A novel disintegrin salmosin inhibits tumor angiogenesis. Cancer Res., 1999, 59, 3754-60.

55 KAWANO K., KANTAK SS., MURAI M., YAO CC., KRAMER RH. Integrin $\alpha 3 \beta 1$ engagement disrupts intercellular adhesion. Exp. Cell Res., 2001, 262, 18096.

56 KIM SI., KIM KS., KIM HS., CHOI MM., KIM DS., CHUNG KH., PARK YS. Inhibition of angiogenesis by salmosin expressed in vitro. Oncol. Res., 2004, $14,227-33$.

57 KIM SI, KIM KS, KIM HS, KIM DS, JANG Y, CHUNG KH, PARK YS. Inhibitory effect of the salmosin gene transferred by cationic liposomes on the progression of B16BL6 tumors. Cancer Res., 2003, 63, 6458-62.

58 KNUDSEN KA., TUSZYNSKI GP., HUANG TF., NIEWIAROWSKI S. Trigramin, an RGD-containing peptide from snake venom, inhibits cell-substratum adhesion of human melanoma cells. Exp. Cell Res., 1988, 179, 42-9.

$59 \mathrm{KOH}$ YS, KIM DS. Characterization and cDNA cloning of a platelet aggregation inhibitor. Mol. Cells., 2000, 10, 437-42.

60 LIDDINGTON RC., GINSBERG MH. Integrin activation takes shape. J. Cell Biol. , 2002, 158, 833-9.

61 LIU CZ., HUANG TF. Crovidisin, a collagen-binding protein isolated from snake venom of Crotalus viridis, prevents platelet-collagen interaction. Arch. Biochem. Biophys., 1997, 337, 291-9. 
62 LIU CZ., PENG HC., HUANG TF. Crotavirin, a potent platelet aggregation inhibitor purified from the venom of the snake Crotalus viridis. Toxicon, 1995, 33, 1289-98.

63 LIPPS BV. Novel snake venom proteins cytolytic to cancer cells in vitro and in vivo systems. J. Venom. Anim. Toxins, 1999, 5, 172-183.

64 MARCINKIEWICZ C., LOBB RR., MARCINKIEWICZ MM., DANIEL JL., SMITH JB., DANGELMAIER C., WEINREB PH., BEACHAM DA., NIEWIAROWSKI S. Isolation and characterization of EMS16, a C-lectin type protein from Echis multisquamatus venom, a potent and selective inhibitor of the $\alpha 2 \beta 1$ integrin. Biochemistry, 2000, 39, 9859-67.

65 MARCINKIEWICZ C., TAOOKA Y., YOKOSAKI Y., CALVETE JJ, MARCINKIEWICZ MM., LOBB RR., NIEWIAROWSKI S., SHEPPARD D. Inhibitory effects of MLDG-containing heterodimeric disintegrins reveal distinct structural requirements for interaction of the integrin $\alpha 9 \beta 1$ with VCAM-1, tenascin-C, and osteopontin. J. Biol. Chem., 2000, 275, 31930-7.

66 MARKLAND FS. Snake venom and the hemostatic system, Toxicon, 1998, 36, 1749-800.

67 MARKLAND FS., SHIEH K., ZHOU Q., GOLUBKOV V., SHERWIN RP, RICHTERS V., SPOSTO R. A novel snake venom disintegrin that inhibits human ovarian cancer dissemination and angiogenesis in an orthotopic nude mouse model. Haemostasis, 2001, 31, 183-91.

68 MARRAKCHI N., SARRAY S., MARVALDI J., EL AYEB M., LUIS J. Effect of Macrovipera lebetina and Cerastes cerastes venoms on adherence to integrins of cancerous cells (IGR39, HT29-D4 and IGROV1). Arch. Inst. Pasteur Tunis., 2002, 79, 3-9.

69 MASUDA S., ARAKI S., YAMAMOTO T., KAJI K., HAYASHI H. Purification of a vascular apoptosis-inducing factor from hemorrhagic snake venom. Biochem. Biophys. Res. Commun.,1997, 235, 59-63.

70 MASUDA S., HAYASHI H., ARAKI S. Two vascular apoptosis-inducing proteins from snake venom are members of the metalloprotease/disintegrin family. Eur. J. Biochem., 1998, 253, 36-41.

71 MCLANE MA., KUCHAR MA., BRANDO C., SANTOLI D., PAQUETTESTRAUB CA., MIELE ME. New insights on disintegrin-receptor interactions: eristostatin and melanoma cells. Haemostasis, 2001, 31, 177-82. 
72 MIZUKAMI Y., LI J., ZHANG X., ZIMMER MA., ILIOPOULOS O., CHUNG DC. Hypoxia-inducible factor-1-independent regulation of vascular endothelial growth factor by hypoxia in colon cancer. Cancer Res., 2004, 64, 1765-72.

73 MORRIS VL., SCHMIDT EE., KOOP S., MACDONALD IC., GRATTAN M, KHOKHA R., MCLANE MA., NIEWIAROWSKI S., CHAMBERS AF., GROOM AC. Effects of the disintegrin eristostatin on individual steps of hematogenous metastasis. Exp. Cell. Res., 1995, 219, 571-8.

74 NAVDAEV A., CLEMETSON JM., POLGAR J., KEHREL BE., GLAUNER M, MAGNENAT E., WELLS TN., CLEMETSON KJ. Aggretin, a heterodimeric C-type lectin from Calloselasma rhodostoma (malayan pit viper), stimulates platelets by binding to $\alpha 2 \beta 1$ integrin and glycoprotein $\mathrm{lb}$, activating Syk and phospholipase $\mathrm{C} \gamma 2$, but does not involve the glycoprotein $\mathrm{VI} / \mathrm{Fc}$ receptor gamma chain collagen receptor. J. Biol. Chem., 2001, 276, 20882-9.

75 NIC, National Cancer Institute, U.S.National Institute of Health (htpp:// www.cancer.gov)

76 OKTAY M., WARY KK., DANS M., BIRGE RB., GIANCOTTI FG. Integrinmediated activation of focal adhesion kinase is required for signaling to Jun $\mathrm{NH} 2$-terminal kinase and progression through the $\mathrm{G} 1$ phase of the cell cycle. J. Cell. Biol., 1999, 145, 1461-9.

77 OKUDA D., MORITA T., Purification and characterization of a new RGD/KGDcontaining dimeric disintegrin, piscivostatin, from the venom of Agkistrodon piscivorus piscivorus: the unique effect of piscivostatin on platelet aggregation. J. Biochem., 2001, 130, 407-15.

78 O'REILLY MS., BOEHM T., SHING Y., FUKAI N., VASIOS G., LANE WS., FLYNN E., BIRKHEAD JR., OLSEN BR., FOLKMAN J. Endostatin: an endogenous inhibitor of angiogenesis and tumor growth. Cell, 1997, 88, 27785.

79 O'REILLY MS., HOLMGREN L., SHING Y., CHEN C., ROSENTHAL RA., MOSES M., LANE WS., CAO Y., SAGE EH., FOLKMAN J. Angiostatin: a novel angiogenesis inhibitor that mediates the suppression of metastases by a Lewis lung carcinoma. Cell, 1994, 79, 315-28.

80 OWENS LV., XU L., CRAVEN RJ., DENT GA., WEINER TM., KORNBERG L., LIU ET., CANCE WG. Overexpression of the focal adhesion kinase (p125FAK) in invasive human tumors. Cancer Res., 1995, 55, 2752-5. 
81 PERL AK., WILGENBUS P., DAHL U., SEMB H., CHRISTOFORI G. A causal role for E-cadherin in the transition from adenoma to carcinoma. Nature, 1998, 392, 190-3.

82 PLAYFORD MP., SCHALLER MD. The interplay between Src and integrins in normal and tumor biology. Oncogene, 2004, 23, 7928-46.

83 POZZI A., ZENT R. Integrins: sensors of extracellular matrix and modulators of cell function. Nephron. Exp. Nephrol., 2003, 94, 77-84.

84 PUBMED, National Center for Biotechnology Information, National Library of Medicine, (http://www.ncbi.nlm.nih.gov/entrez/query.fcgi?db=PubMed)

85 RITTER MR., MARKLAND FS JR. Differential regulation of tyrosine phosphorylation in tumor cells by contortrostatin, a homodimeric disintegrin, and monomeric disintegrins echistatin and flavoridin. Toxicon, 2001, 39, 2839.

86 RUPP PA., LITTLE CD. Integrins in vascular development. Circ. Res., 2001, 89, 566-72.

87 RUST WL., CARPER SW., PLOPPER GE. The promise of integrins as effective targets for anticancer agents. J. Biomed. Biotechnol., 2002, 2, 124-30.

88 SARRAY S., BERTHET V., CALVETE JJ., SECCHI J., MARVALDI J., ELAYEB M., MARRAKCHI N., LUIS J. Lebectin, a novel C-type lectin from Macrovipera lebetina venom, inhibits integrin-mediated adhesion, migration and invasion of human tumour cells. Lab. Invest., 2004, 84, 573-81.

89 SCARBOROUGH RM., ROSE JW., HSU MA., PHILLIPS DR., FRIED VA., CAMPBELL AM., NANNIZZI L., CHARO IF. Barbourin. A GPIIb-IIla-specific integrin antagonist from the venom of Sistrurus m. barbouri. J. Biol. Chem., 1991, 266, 9359-62.

90 SCHLAEPFER DD., MITRA SK. Multiple connections link FAK to cell motility and invasion. Curr. Opin. Genet. Dev., 2004, 14, 92-101.

91 SCHLAEPFER DD., MITRA SK., ILIC D. Control of motile and invasive cell phenotypes by focal adhesion kinase. Biochim. Biophys. Acta., 2004, 1692, 77-102.

92 SCHWARTZ MA., ASSOIAN RK. Integrins and cell proliferation: regulation of cyclin-dependent kinases via cytoplasmic signaling pathways. J. Cell. Sci., $2001,114,2553-60$. 
93 SCHWARTZ MA., INGBERT DE. Integrating with Integrins. Molec. Biol. Cell, 1994, 5, 389-93.

94 SENGER DR., CLAFFEY KP., BENES JE., PERRUZZI CA., SERGIOU AP., DETMAR M. Angiogenesis promoted by vascular endothelial growth factor: regulation through $\alpha 1 \beta 1$ and $\alpha 2 \beta 1$ integrins. Proc. Natl. Acad. Sci. U.S.A., 1997, 94, 13612-7.

95 SENGER DR., LEDBETTER SR., CLAFFEY KP., PAPADOPOULOS-SERGIOU A., PERUZZI CA., DETMAR M. Stimulation of endothelial cell migration by vascular permeability factor/vascular endothelial growth factor through cooperative mechanisms involving the $\alpha \mathrm{v} \beta 3$ integrin, osteopontin, and thrombin. Am. J. Pathol., 1996, 149, 293-305.

96 SEPP NT., LI LJ., LEE KH., BROWN EJ., CAUGHMAN SW., LAWLEY TJ., SWERLICK RA. Basic fibroblast growth factor increases expression of the $\alpha v \beta 3$ integrin complex on human microvascular endothelial cells. J. Invest. Dermatol., 1994, 103, 295-9.

97 SHATTIL SJ., GINSBERG MH. Integrin signaling in vascular biology. J. Clin. Invest., 1997, 100, 91-5.

98 SHEU JR., LIN CH., PENG HC., HUANG TF. Triflavin, an Arg-Gly-Aspcontaining peptide, inhibits the adhesion of tumor cells to matrix proteins via binding to multiple integrin receptors expressed on human hepatoma cells. Proc. Soc. Exp. Biol. Med., 1996, 213, 71-9.

99 SHEU JR., YEN MH., KAN YC., HUNG WC., CHANG PT., LUK HN. Inhibition of angiogenesis in vitro and in vivo: comparison of the relative activities of triflavin, an Arg-Gly-Asp-containing peptide and anti- $\alpha \mathrm{v} \beta 3$ integrin monoclonal antibody. Biochim. Biophys. Acta., 1997, 1336, 445-54.

100 SILVA CA., ZULIANI JP., ASSAKURA MT., MENTELE R., CAMARGO AC, TEIXEIRA CF., SERRANO SM. Activation of $\alpha M \beta 2$-mediated phagocytosis by HF3, a P-III class metalloproteinase isolated from the venom of Bothrops jararaca. Biochem. Biophys. Res. Commun., 2004, 322, 950-6.

101 SMITH SK. Regulation of angiogenesis in the endometrium. Trends Endocrinol. Metab., 2001,12,147-51. 
102 SPRINGER TA., WANG JH. The three-dimensional structure of integrins and their ligands, and conformational regulation of cell adhesion. Adv. Protein. Chem., 2004, 68, 29-63.

103 STEPHENS LE., SUTHERLAND AE., KLIMANSKAYA IV., ANDRIEUX A., MENESES J., PEDERSEN RA., DAMSKY CH. Deletion of $\beta 1$ integrins in mice results in inner cell mass failure and peri-implantation lethality. Genes Dev., 1995, 9, 1883-95.

104 STOELTZING O., MCCARTY MF., WEY JS., FAN F., LIU W., BELCHEVA A., BUCANA CD., SEMENZA GL., ELLIS LM. Role of hypoxia-inducible factor $1 \alpha$ in gastric cancer cell growth, angiogenesis, and vessel maturation. J. Natl. Cancer Inst., 2004, 96, 946-56.

105 SWENSON S., COSTA F., MINEA R., SHERWIN RP., ERNST W., FUJII G, YANG D, MARKLAND FS JR. Intravenous liposomal delivery of the snake venom disintegrin contortrostatin limits breast cancer progression. Mol. Cancer Ther., 2004, 3, 499-511.

106 TANG CH., YANG RS., LIU CZ., HUANG TF., FU WM. Differential susceptibility of osteosarcoma cells and primary osteoblasts to cell detachment caused by snake venom metalloproteinase protein. Toxicon, $2004,43,11-20$.

107 TOMAR S., YADAV S., CHANDRA V., KUMAR P., SINGH TP. Purification, crystallization and preliminary X-ray diffraction studies of disintegrin (schistatin) from saw-scaled viper (Echis carinatus). Acta Crystallogr. D. Biol. Crystallogr., 2001, 57, 1669-70.

108 TOZER EC., HUGHES PE., LOFTUS JC. Ligand binding and affinity modulation of integrins. Biochem. Cell Biol., 1996, 74, 785-98.

109 TSUZUKI Y., FUKUMURA D., OOSTHUYSE B., KOIKE C., CARMELIET P., JAIN RK. Vascular endothelial growth factor (VEGF) modulation by targeting hypoxia-inducible factor- $1 \alpha \rightarrow$ hypoxia response element $\rightarrow$ VEGF cascade differentially regulates vascular response and growth rate in tumors. Cancer Res., 2000, 60, 6248-52.

110 VAN DER FLIER A., SONNENBERG A. Function and interactions of integrins. Cell Tissue Res., 2001, 305, 285-98. 
111 WALTON HL., CORJAY MH., MOHAMED SN., MOUSA SA., SANTOMENNA LD., REILLY TM. Hypoxia induces differential expression of the integrin receptors $\alpha v \beta 3$ and $\alpha v \beta 5$ in cultured human endothelial cells. J. Cell Biochem., 2000, 78, 674-80.

112 WANG R., KINI RM., CHUNG MC. Rhodocetin, a novel platelet aggregation inhibitor from the venom of Calloselasma rhodostoma (Malayan pit viper): synergistic and noncovalent interaction between its subunits. Biochemistry, 1999, 38, 7584-93.

113 WOZNIAK MA., MODZELEWSKA K., KWONG L., KEELY PJ. Focal adhesion regulation of cell behavior. Biochem. Biophys. Acta., 2004, 1692, 103-19.

114 YEH CH., PENG HC., HUANG TF. Accutin, a new disintegrin, inhibits angiogenesis in vitro and in vivo by acting as integrin $\alpha \mathrm{v} \beta 3$ antagonist and inducing apoptosis. Blood, 1998, 92, 3268-76.

115 YEH CH., PENG HC., YANG RS., HUANG TF. Rhodostomin, a snake venom disintegrin, inhibits angiogenesis elicited by basic fibroblast growth factor and suppresses tumor growth by a selective $\alpha v \beta 3$ blockade of endothelial cells. Mol. Pharmacol., 2001, 59, 1333-42.

116 YOU WK., SEO HJ., CHUNG KH., KIM DS. A novel metalloprotease from Gloydius halys venom induces endothelial cell apoptosis through its protease and disintegrin-like domains. J. Biochem., 2003, 134, 739-49.

117 ZHAO Q., WANG N., JIA R., ZHANG S., MIAO J. Integrin $\beta 4$ is a target of rattlesnake venom during inducing apoptosis of vascular endothelial cells. Vascul. Pharmacol., 2004, 41, 1-6.

118 ZHOU Q., NAKADA MT., BROOKS PC., SWENSON SD., RITTER MR., ARGOUNOVA S., ARNOLD C., MARKLAND FS. Contortrostatin, a homodimeric disintegrin, binds to integrin $\alpha \mathrm{v} \beta 5$. Biochem. Biophys. Res. Commun., 2000, 267, 350-5. 